\title{
Implications of Distraction Osteogenesis in Ankylosis of Temporomandibular Joint
}

\section{Implicações da Distração Osteogênica na Anquilose da Articulação Temporomandibular}

\author{
Lucas Sambugaro ${ }^{\text {a; }}$ Isabela Toledo Teixeira da Silveira ${ }^{\text {b; }}$ Ercio Junior Montenegro de Andrade ${ }^{c}$; Marina de Almeida \\ Barbosa Mello ; Ana Carolina Bonetti Valented; Renato Yassutaka Faria Yaedú*b
}

${ }^{a}$ University of São Paulo Graduated in Dentistry School. SP, Brazil.

bUniversity of São Paulo, Bauru School of Dentistry, Stricto Sensu Graduate Program in Dentistry. SP, Brazil.

'University of São Paulo, Hospital for Rehabilitation of Craniofacial Anomalies. SP, Brazil.

dUniversity of São Paulo, Hospital for Rehabilitation of Craniofacial Anomalies. SP, Brazil.

*E-mail: renatoyaedu@gmail.com.

Recebido em: 30/06/2020

Aprovado em : 30/09/2020

\begin{abstract}
Studies with children and adult patients submitted to mandibular distraction osteogenesis surgery were analyzed, whose complication was ankylosis of the temporomandibular joint. In this study, the objective was to carry out a narrative review of the literature, seeking the prevalence of this complication after distraction osteogenesis. The literature review was carried out in the electronic databases, PubMed and Scopus, using mesh terms and their respective entry terms. The screening process consisted of two phases: Phase I - Select by titles and abstracts; Phase II - Complete reading article based on selected articles from phase I. It was observed after the data tabulation a lack of scientific evidence regarding this complication after distraction osteogenesis; as well as a very large variability in the case report studies or case series since there are no clinical trials on this subject. Thus, it can be concluded that there are few studies to state the relationship between ankylosis of the temporomandibular joint after distraction osteogenesis, requiring further clinical trial studies on the subject.
\end{abstract}

Keywords: Temporomandibular Joint Dysfunction Syndrome. Temporomandibular Joint Disorders. Osteogenesis. Distraction. Callotasis; Bone Formation.

\section{Resumo}

Foram analisados estudos com pacientes crianças e adultos submetidos a cirurgia de distração osteogênica mandibular que tiveram como complicação a anquilose da articulação temporo-mandibular. Neste estudo o objetivo foi realizar uma revisão narrativa da literatura buscando a prevalência desta complicação após a distração osteogênica. A revisão de literatura foi realizada nas bases de dados eletrônicas, PubMed e Scopus, utilizando mesh terms e seus respectivos entry terms. O processo de triagem consistiu em duas fases: Fase I - Selecionar por títulos e resumos; Fase II- Artigo completo de leitura baseado em artigos selecionados da fase I. Observou-se após a tabulação dos dados a falta de evidência científica com relação a esta complicação após a distração osteogênica; bem como uma variabilidade muito grande nos trabalhos de relato de caso ou série de casos uma vez que não existem ensaios clínicos referente a este assunto. Desta forma pode-se concluir que há poucos estudos para afirmarmos a relação entre a anquilose da articulação temporo-mandibular após a distração osteogênica, sendo necessários mais estudos de ensaio clínico sobre o tema.

Palavras-chave: Síndrome da Disfunção da Articulação Temporomandibular. Transtornos da Articulação Temporomandibular. Calotasia. Formação Óssea.

\section{Introduction}

Ankylosis of the temporomandibular joint (TMJ) is defined as the fusion of the joint component surfaces (hard and soft tissues). It tends to occur in children and adolescent patients. The most important clinical manifestation of TMJ ankylosis is the limitation or inability to perform mandibular movements. ${ }^{1}$

Ankylosis causes significant delay in mandibular growth in horizontal and vertical planes. ${ }^{2}$ The extent of growth retardation depends on the onset, severity and duration of the aggression to TMJ. Patients with unilateral ankylosis of TMJ present jaw asymmetry with or without retrognathism, while the patient with bilateral ankylosis has moderate to severe retrognathism that may lead to obstructive sleep apnea. ${ }^{3}$
Ankylosis of the temporomandibular joint can be classified in the following ways: anatomically, as intracapsular or extracapsular; according to the tissue involved in the bone, as fibrous or fibro-osseous; and according to the fusion extent, as complete or incomplete. ${ }^{4}$

Restoring proportional anatomy and facial features is a challenge in these patients. ${ }^{3}$ The main cause of ankylosis is due to trauma on the face followed by local or systemic infection, such as ankylosing spondylitis and rheumatoid arthritis. Ankylosis can also be a sequel of mandibular distraction osteogenesis. ${ }^{3,4}$

Its success with jaw stretching and subsequent reports of successful tracheostomy decannulation after mandibular distraction in patients with Robin sequence (SR) led to an increase in the use of mandibular distraction to avoid 
tracheostomy in these patients. ${ }^{5}$

Early mandibular distraction in patients with severe micrognathia has recently been recognized as an effective treatment option to relieve upper airway obstruction, since the airway improvement mechanism is mainly based on the jaw advance and the posterior anterior displacement of the tongue base and epiglottis away from the posterior pharynx wall. ${ }^{6}$

Mandibular distraction osteogenesis, in addition to aiming for a pervious airway, has as function to recover the morphology with normal growth, adequate speech development, dental occlusion and normal growth of the facial skeleton.?

The technique has been used for correction of congenital or acquired jaw deformity. With more experiences and longterm follow-up, complications of mandibular distraction osteogenesis and sequels of TMJ were demonstrated, including studies of syndromic patients. ${ }^{8}$

Micrognathia, or hypoplastic jaw, resulting from abnormal development of the lower face, may occur alone or as part of a craniofacial syndrome. Mild neonatal cases may be asymptomatic or may have intermittent upper airway obstruction. ${ }^{8}$ When severe, micrognathia may present itself as a medical emergency of the airways, with the tongue retro positioned in the oropharynx as a result of the hypoplastic jaw. This obstruction requires immediate intervention, such as prone positioning, orotracheal airways, intubation and mechanical ventilation, lip/lingual adherence or tracheostomy. Micrognathia, if not resolved, results in malocclusion, which may cause difficulties in feeding, dysfunction of the temporomandibular joint and aesthetic dissatisfaction, the main treatment of this disorder being distraction osteogenesis with the objective of performing the mandibular stretching. ${ }^{9}{ }^{910}$ The main cause of ankylosis is trauma, followed by local or systemic infection, such as ankylosing spondylitis and rheumatoid arthritis. Ankylosis can also be a result of a mandibular distraction surgery that was not successful., 9

The objective of this study was to verify in the literature the relationship between distraction osteogenesis and the ankylosis development of temporomandibular joint.

\section{Development}

\subsection{Methodology}

"PICO" strategy, meaning population (population/ participants), intervention (intervention/exposure for observational studies), comparator (comparison) and results (outcome), and PRISMA platform that organized and identified the work in flowchart, was performed as a methodological way to review the literature narrative.

Data search was performed in the PubMed and Scopus electronic databases to identify all potentially relevant studies. The following criteria were formulated to select the articles (Table 1) and the following mesh terms were used; Micrognathism;Retrognathia/ Osteogenesis, Distraction/ Tracheostomy; Orthognathic Surgery;
Orthognathic Surgical Procedures/ Temporomandibular Joint Disorders;Temporomandibular ankylosis; Ankylosis and its respective entry terms adapted for each data basis (Table 2).

Table 1 - Inclusion and Exclusion Criteria

\begin{tabular}{|c|c|}
\hline & \\
\hline $\begin{array}{l}\text { - } \text { Cases Reports } \\
\text { - Comparative study; } \\
\text { Controlled Clinical Trial } \\
\text { - Adult patients and children } \\
\text { submitted to mandibular } \\
\text { distraction osteogenesis } \\
\text { - Studies published in the } \\
\text { last } 10 \text { years. }\end{array}$ & $\begin{array}{l}\text { Patients who had } \\
\text { previously ankylosis of } \\
\text { the temporo-mandibular } \\
\text { joint before the procedure } \\
\text { of mandibular distraction } \\
\text { osteogenesis } \\
\text { Articles in languages other } \\
\text { than English }\end{array}$ \\
\hline
\end{tabular}

Source: Research data.

Table 2 - Search strategy for identification of studies in electronic databases

\begin{tabular}{|c|c|}
\hline Mesh terms & Entry terms \\
\hline "Micrognatism" & $\begin{array}{c}\text { Micrognathism } \\
\text { Micrognathisms } \\
\text { Mandibular Micrognathism } \\
\text { Mandibular Micrognathisms } \\
\text { Micrognathism, Mandibular } \\
\text { Micrognathisms, Mandibular } \\
\text { Micrognathia } \\
\text { Micrognathias } \\
\text { Congenital Micrognathism } \\
\text { Congenital Micrognathisms } \\
\text { Micrognathism, Congenital } \\
\text { Micrognathisms, Congenital } \\
\text { Congenital Micrognathia } \\
\text { Congenital Micrognathias } \\
\text { Micrognathia, Congenital } \\
\text { Micrognathias, Congenital } \\
\text { Mandibular Micrognathia } \\
\text { Mandibular Micrognathias } \\
\text { Micrognathia, Mandibular } \\
\text { Micrognathias, Mandibula }\end{array}$ \\
\hline "Retrognathia" & $\begin{array}{c}\text { Retrognathias } \\
\text { Retrognathism } \\
\text { Retrognathisms } \\
\text { Maxillary Retroposition } \\
\text { Maxillary Retropositions } \\
\text { Retroposition, Maxillary } \\
\text { Retropositions, Maxillary } \\
\text { Maxillary Retrusion } \\
\text { Maxillary Retrusions } \\
\text { Retrusion, Maxillary } \\
\text { Retrusions, Maxillary } \\
\text { Mandibular Retroposition } \\
\text { Mandibular Retropositions } \\
\text { Retroposition, Mandibular } \\
\text { Retropositions, Mandibular } \\
\text { Mandibular Retrusion } \\
\text { Mandibular Retrusions } \\
\text { Retrusion, Mandibular } \\
\text { Retrusions, Mandibular }\end{array}$ \\
\hline $\begin{array}{l}\text { "Osteogenesis, } \\
\text { Distraction" }\end{array}$ & $\begin{array}{c}\text { Distraction Osteogenesis } \\
\text { Distraction Osteogeneses } \\
\text { Osteogeneses, Distraction } \\
\text { Callotasis } \\
\text { Callotases } \\
\end{array}$ \\
\hline "Tracheostomy" & Tracheostomies \\
\hline
\end{tabular}




\begin{tabular}{|c|c|}
\hline Mesh terms & Entry terms \\
\hline $\begin{array}{l}\text { "Orthognathic } \\
\text { Surgery" }\end{array}$ & $\begin{array}{c}\text { Orthognathic Surgeries } \\
\text { Surgeries, Orthognathic } \\
\text { Surgeries, Orthognathic } \\
\text { Surgery, Orthognathic } \\
\text { Maxillofacial Orthognathic Surgery } \\
\text { Maxillofacial Orthognathic Surgeries } \\
\text { Orthognathic Surgeries, Maxillofacial } \\
\text { Orthognathic Surgery, Maxillofacial } \\
\text { Surgeries, Maxillofacial Orthognathic } \\
\text { Surgery, Maxillofacial Orthognathic } \\
\text { Jaw Surgery } \\
\text { Jaw Surgeries } \\
\text { Surgeries, Jaw } \\
\text { Surgery, Jaw } \\
\end{array}$ \\
\hline $\begin{array}{l}\text { "Orthognathic } \\
\text { Surgical Procedures" }\end{array}$ & $\begin{array}{l}\text { Orthognathic Surgical Procedure } \\
\text { Procedure, Orthognathic Surgical } \\
\text { Procedures, Orthognathic Surgical } \\
\text { Surgical Procedure, Orthognathic } \\
\text { Surgical Procedures, Orthognathic }\end{array}$ \\
\hline $\begin{array}{l}\text { "Temporomandibular } \\
\text { Joint Disorders" }\end{array}$ & $\begin{array}{c}\text { Disorder, Temporomandibular Joint } \\
\text { Disorders, Temporomandibular Joint } \\
\text { Joint Disorder, Temporomandibular } \\
\text { Joint Disorders, Temporomandibular } \\
\text { Temporomandibular Joint Disorder } \\
\text { TMJ Disorders } \\
\text { Disorder, TMJ } \\
\text { Disorders, TMJ } \\
\text { TMJ Disorder } \\
\text { Temporomandibular Disorders } \\
\text { Disorder, Temporomandibular } \\
\text { Disorders, Temporomandibular } \\
\text { Temporomandibular Disorder } \\
\text { Temporomandibular Joint Diseases } \\
\text { Disease, Temporomandibular Joint } \\
\text { Diseases, Temporomandibular Joint } \\
\text { Joint Disease, Temporomandibular } \\
\text { Joint Diseases, Temporomandibular } \\
\text { Temporomandibular Joint Disease } \\
\text { TMJ Diseases } \\
\text { Disease, TMJ } \\
\text { Diseases, TMJ } \\
\text { TMJ Disease }\end{array}$ \\
\hline $\begin{array}{l}\text { "Temporomandibular } \\
\text { ankylosis" }\end{array}$ & - \\
\hline "Ankylosis" & \\
\hline
\end{tabular}

Source: Research data.

For the selection of the studies, studies on human beings were established as inclusion criteria and presented ankylosis as a complication of distraction osteogenesis and not as a precondition for distraction osteogenesis.

The articles were selected in two steps

After the first search, the duplicate studies were removed and then examined by the title and then abstract reading.

In cases where the study seemed to be eligible, but the data, in the title and in the abstract, were insufficient to make a clear decision, this was selected for further evaluation with the full text.

Therefore, the screening process consisted of two stages:

1. Stage I - Selection by titles and abstracts

2. Phase II- Full reading article based on Stage I selected articles

\subsection{Results and Discussion}

The search identified a sum of 68 articles in the two databases. Of these, no articles were duplicated. 41 articles whose titles were not on the ankylosis subject after distraction osteogenesis were excluded. A total of 27 articles were selected by reading the title/abstract, of which 15 were not in accordance with the criteria. Of the 12 articles which were completely read, 9 of them were selected.

Figure 1 shows the PRISM Flowchart of the study selection process.

Figure 1 - Flowchart of the articles selection procedure

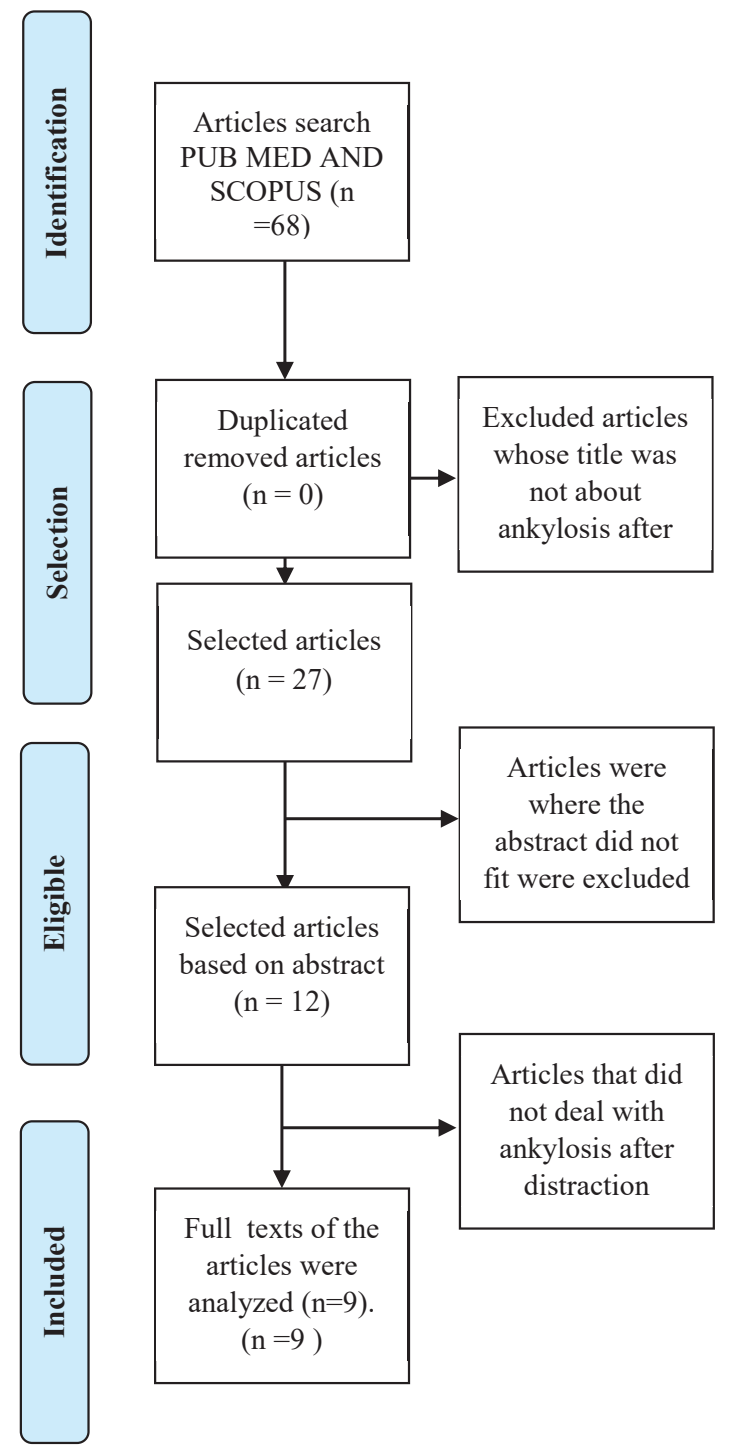

Source: The authors.

The reasons for excluding the articles in the first stage included texts in languages other than English, sample of patients who already presented ankylosis of the temporomandibular joint, literature review.

Table 3 describes all the studies that fit the review according to the authors and year of publication, number of patients, whether the ankylosis presented in the study was bone or fibrous, whether the group of patients were syndromic 
and the age when the distraction osteogenesis procedure was performed.

The objective of this study was to analyze in the literature the studies that presented ankylosis of the temporomandibular joint as a complication of distraction osteogenesis.

There are few studies available in the literature regarding this theme, and it is extremely important to know the factors predisposing to this complication, as well as ways to avoid it. Distraction osteogenesis is a widely used procedure to lengthen bone structures, being applied in patients with micrognathia and this condition is mainly present in patients with syndromes such as Robin sequence, Goldenhar syndrome, Treacher Collins syndrome (hypoplastic facies, oculo-palpebral anomalies), Nager syndrome (radial deficiency, acrofacial dysostosis), Stickler syndrome ( cleft palate, degenerative arthropathy, ocular abnormalities) and other craniofacial deformities. ${ }^{10-12}$

Most of the studies included in the review point to the predominance of ankylosis as a complication of distraction osteogenesis in syndromic patients (7 studies).

This fact is reinforced in the study of Andrews and collaborators, who showed that only syndromic patients developed ankylosis of the temporomandibular joint. ${ }^{13}$

In the work developed by Schlund et al. ${ }^{14}$ a retrospective analysis of three syndromic patients who presented micrognathia were submitted to distraction osteogenesis and all patients developed ankylosis of the temporomandibular joint after the procedure.

Similarly, in the study carried out by Galié and collaborators, two clinical cases of two children with severe micrognathia and respiratory discomfort at birth were reported. Early distraction osteogenesis was performed during the first 2 months of life with the objective of increasing the mandibular length and increasing the capacity of air passing through the upper airways. However, both patients presented severe oral opening restriction after distraction osteogenesis and mandibular abnormalities, the first patient was submitted to distraction osteogenesis surgery at 10 years and the second at 2 years of age. In both patients, complementary treatments of physiotherapy and other surgeries, such as coronoidectomy were performed. Thus, the work concluded that the planning and selection of a vector of appropriate distraction is of paramount importance at the beginning of distraction osteogenesis to avoid serious complications, and affirm that the ankylosis of the temporomandibular joint after early mandibular distraction can be considered a follow-up associated with the procedure. ${ }^{15}$

This complication can be explained due to the mandibular anatomy alteration that occurs in these patients, and the altered anatomy of the temporomandibular joint may place syndromic patients at risk of perioperative complications of the temporomandibular joint due to the increase of the load per unit of area in the hypoplastic condyles. ${ }^{4}$

An alternative to minimize the occurrence of this complication is mentioned in the study by Fan et al. ${ }^{10}$ who although cite an increased incidence of condylar pathology (narrowing of the joint space (15 percent, nine of 60) and bone spikes between condyle and glenoid fossa) in the preoperative period in syndromic micrognathia compared to non-syndromic patients. Radiographically and clinically, syndromic patients had worse results of temporomandibular joint compared to non-syndromic patients after the distraction. They modified the distraction technique with the use of class II elastic bands during the active distraction phase and compared the condyles with and without loads (those with elastic bands). The cases without load had better results in the temporomandibular joints. Although this technique does not completely unload the condyle, the syndromic patients in our study benefit from this anatomical and functionally intervention.

The knowledge about the alterations that occur in the temporomandibular joint region during mandibular distraction osteogenesis is, however, limited and controversial, as stated by Kofod et al in 2005 , the authors justify this statement because it is difficult to measure the force applied in the temporomandibular joint in vivo, since the process would be extremely invasive. ${ }^{6}$

Therefore, it can be considered unlikely that the forces generated by the distraction process are high to generate harmful effects on human TMJs. ${ }^{6,7}$

In her work Xiao (2019) addresses a theory about this difference which is related to the distraction vector; a vertical vector is more likely to lead to TMJ ankylosis because of the cranially driven pressure supported by TMJ during activation, in comparison with the horizontal or obliquely directed vector, the objective of this study was to retrospectively evaluate the medical records of patients submitted to mandibular distraction at the Children's Mercy Hospital from 1997 to 2015. All the operations were performed by 3 surgeons. The ankylosis rates were compared between the 2 groups and as a result they obtained TMJ ankylosis in 12 cases, all in the vertical vector group, a rate of $17 \%$ of ankylosis. There were no cases of ankylosis in the oblique vector group. The authors concluded that vertical mandibular distraction carries a significantly increased risk of TMJ ankylosis and should be avoided. $^{9}$

The Nager syndrome, also known as the acrofacial dysostosis of Nager, patients usually have micrognathia, and a preventive tracheostomy is necessary when there are symptoms of upper airway obstruction. ${ }^{10,11}$ In the study by Wu and collaborators the authors reported two patients with Nager syndrome suffering from TMJ ankylosis after mandibular distraction osteogenesis the authors state that multiple factors are related to ankylosis of the temporomandibular joints after mandibular distraction osteogenesis in patients with Nager syndrome. The prevention of post-distraction ankylosis of joints is important because treatment is difficult and not always effective. Therefore, they consider that further studies on the joints protection during the mandibular distraction are 
necessary in the future. ${ }^{16}$

Also, regarding complications related to the distraction osteogenesis process, Master and his research group (2010) conducted a literature review, and accessed the PubMed database, where they obtained articles describing the complications of mandibular distraction osteogenesis. Each Article has been revised and the relevant data have been extracted and compiled. Finally, several case reports are presented to illustrate pungent examples of complications. Since they included recurrence $(64.8 \%$ incidence $)$, dental injury $(22.5 \%)$, hypertrophic scar $(15.6 \%)$, nervous injury (11.4\%), infection (9.5\%), inappropriate deviation $(8.8 \%)$, device failure $(7.9 \%)$, fusion error $(2.4 \%)$ and temporomandibular joint injury $(0.7 \%)$. Thus, they stated that mandibular distraction osteogenesis may be associated with a wide variety of minor and major complications, but all complications can be avoided with adequate preoperative planning, intraoperative meticulous technique and complete postoperative management. ${ }^{8}$

There is no consensus in the literature, since there are studies that show that there is no incidence of sequels in the temporomandibular joint after distraction osteogenesis ${ }^{12}$, while others show relatively high rates of $10 \%$ of the problem occurrence ${ }^{15,16}$

Table 3 describes all the studies that fit the review according to the authors and year of publication, number of patients, whether the ankylosis presented in the study was bone or fibrous, whether the group of patients were syndromic and the age when the distraction osteogenesis procedure was performed.

Table 3 - Description of the selected articles

\begin{tabular}{|c|c|c|c|c|c|}
\hline Articles & Number of Patients & Bone ankylosis & Fibrous ankylosis & Syndromic & $\begin{array}{c}\text { Age when the } \\
\text { Distraction } \\
\text { osteogenesis was } \\
\text { performed } \\
\end{array}$ \\
\hline Fan et al. (2012) & 25 & $\begin{array}{c}\text { (4 bilateral and } 1 \\
\text { unilateral })\end{array}$ & 4 & yes & (not informed) \\
\hline Galié et al. (2017) & 2 & $2(?)$ & (not informed) & yes & (not informed) \\
\hline Murage et al. (2014) & 50 & $10 \%$ & (not informed) & yes & 3 months \\
\hline Wu et al. (2017) & 2 & 2 & (not informed) & yes & (not informed) \\
\hline Schlund, M (2020) & 3 & 2 & 1 & yes & (not informed) \\
\hline Ow; Cheung (2008) & 1185 & 26 & (not informed) & no & $\begin{array}{l}\text { up to } 2 \text { years } \\
2 \text { to } 5 \text { years }\end{array}$ \\
\hline $\begin{array}{l}\text { Schlieve et al. } \\
(2012)\end{array}$ & 48 & $\begin{array}{c}2 \text { (it does not make } \\
\text { it clear in the article } \\
\text { whether it is bone or } \\
\text { fibrous) }\end{array}$ & (not informed) & yes & (not informed) \\
\hline $\begin{array}{l}\text { Andrews, Brian } \\
\text { T. (2013) }\end{array}$ & 73 & $10 \%$ (not clear) & (not informed) & $10 \%$ syndromic & 6 years \\
\hline
\end{tabular}

Source: Research data.

\section{Conclusion}

It can be concluded that TMJ ankylosis is a distraction osteogenesis complication. It occurs more in patients with associated syndromes. There are few studies that point to scientific evidence regarding the cost-benefit of performing this technique at the expense of the complication that can occur.

More controlled clinical studies are necessary to assess the main factors related to this complication and its prevalence.

\section{References}

1. Allori AC, Chang CC, Fariña R, Grayson BH, Warren SM, McCarthy JG. Current Concepts in Pediatric Temporomandibular Joint Disorders: Part 1. Etiol Epidemiol Classification, 2010;126(4);1263-75. doi: 10.1097/ PRS.0b013e3181ebe207

2. Hong P. A clinical narrative review of mandibular distraction osteogenesis in neonates with Pierre Robin sequence. Int $\mathbf{J}$ Pediatr Otorhinolaryngol 2011;75:985-91. doi: https://doi. org/10.1016/j.ijporl.2011.05.003

3. Rowe NL. Ankylosis of the temporomandibular joint. J R Coll Surg Edinb 1982;27:67-79

4. Fan K, Andrews BT, Liao E, Allam K, Raposo Amaral CA, Bradley JP. Protection of the temporomandibular joint during syndromic neonatal mandibular distraction using condylar unloading. Plast Reconstr Surg 2012;129(5):1151-61. doi: 10.1097/PRS.0b013e31824a2d00.

5. Cascone P, Gennaro P, Spuntarelli G, Iannetti G. Mandibular distraction: evolution of treatment protocols in hemifacial microsomy. J Craniofac Surg 2005;16(4):563-71. doi: 10.1097/SCS.0000000000001416

6. Kofod T, Cattaneo PM, Dalstra M, Melsen B. Threedimensional finite elemento analysis of the mandible and temporomandibular joint during vertical ramus elongation by distraction osteogenesis. J Craniofac Surg 2005;16(4):58693.

7. Hamada T, Ono T, Otsuka R, Honda E, Harada K, Kurabayashi $\mathrm{T}$, et al. Mandibular distraction osteogenesis in a skeletal Class II patient with obstructive sleep apnea. Am J Orthod Dentofacial Orthop 2007;131(3):415-25. doi: 10.1097/ 


\section{SCS.0b013e3181577aab}

8. Master DL, Hanson PR, Gosain AK. Complications of mandibular distraction osteogenesis. J Craniofac Surg 2010;21(5):1565-70. doi: 10.1097/SCS.0b013e3181ecc6e5.

9. Xiao K, Goldstein J, Hendricks H, Lypka M. Does Mandibular Distraction Vector Influence the Rate of Temporomandibular Joint Ankylosis? Plast Reconstr Surg Glob Open. 2019;7:6666. doi: 10.1097/01.GOX.0000584588.50444.cb. PMCID: PMC6750552.

10. Fan K, Andrews BT, Liao E, Allam K, Raposo Amaral CA, Bradlev JP. Protection of the temporomandibular joint during syndromic neonatal mandibular distraction using condylar unloading. Plast Reconstr Surg 2012;129:1151-61 doi: 10.1097/PRS.0b013e31824a2d00

11. Schlieve T, Almusa M, Miloro M, Kolokythas A. Temporomandibular joint replacement for ankylosis correction in Nager syndrome: case report and review of the literature. J Oral Maxillofac Surg 2012;70(3):616-25. doi: 10.1016/j.joms.2011.02.053.

12. Murage KP, Costa MA, Friel MT, Havlik RJ, Tholpady SS, Flores RL. Complications associated with neonatal mandibular distraction osteogenesis in the treatment of Robin sequence. J Craniofac Surg 2014;25(2):383-7. doi: 10.1097/ SCS.0000000000000640.

13. Andrews BT, Fan KL, Roostaeian J, Federico CBA, Bradley, JP. Incidence of Concomitant Airway Anomalies When Using the University of California, Los Angeles, Protocol for Neonatal Mandibular Distraction, Plastic and Reconstructive Surgery 2013;131(5):1116-23. doi: 10.1097/ PRS.0b013e3182865da0

14. Schlund M, Touzet-Roumazeille S, Nicot R, Ferri J. Temporomandibular Joint Ankylosis Following Mandibular Distraction Osteogenesis: A Dreadful Complication. J Craniofac Surg 2020;31(1):222-5. doi: 10.1097/SCS.0000000000005911.

15. Galié M, Candotto V, Elia G, Clauser LC. Temporomandibular Joint Ankylosis After Early Mandibular Distraction Osteogenesis: A New Syndrome? J Craniofac Surg 2017;28(5):1185-90. doi: 10.1097/SCS.0000000000003612.

16. 16.Wu CC, Sakahara D, Imai K. Ankylosis of temporomandibular joints after mandibular distraction osteogenesis in patients with Nager syndrome: Report of two cases and literature review. J Plast Reconstr Aesthet Surg 2017;70(10):1449-56. doi: 10.1016/j.bjps.2016.12.014. 